\title{
APPLICATION OF ENERGY AND EXERGY ANALYSES TO A CI ENGINE USING BIODIESEL FUEL
}

\author{
Perihan Sekmen ${ }^{1}$, Zeki Yılbaşı ${ }^{2}$ \\ ${ }^{1}$ Karabuk University, Technical Education Faculty, Department of Mechanical \\ Education, 78200, Karabuk, Turkey \\ ${ }^{2}$ Bozok University, Akdağmadeni Vocational Collage, 66500, Yozgat, Turkey \\ perduranli@yahoo.com,psekmen@karabuk.edu.tr
}

\begin{abstract}
In recent years, exergy analysis method has been widely used in the design, simulation and performance assessment of various types of engines for identifying losses and efficiencies. In this study, the first and second Laws of thermodynamics are employed to analyze the quantity and quality of energy in a four-cylinder, direct injection diesel engine using petroleum diesel fuel and biodiesel fuel. The experimental data were collected using steady-state tests which enable accurate measurements of air, fuel and cooling water flow rates, engine load, and all the relevant temperatures. Balances of energy and exergy rates for the engine were determined and then various performance parameters and energy and exergy efficiencies were calculated for each fuel operation and compared with each other. The results of tested biodiesel offer similar energetic performance as petroleum diesel fuel. In addition to this, the exergetic performance parameters usually follow similar trends according to the energetic performance parameters.
\end{abstract}

Key Words- Diesel engine, energy analysis, exergy analysis, biodiesel.

\section{INTRODUCTION}

The petroleum fuels play a very important role in the development of industrial growth, transportation, agricultural sector and to meet many other basic human needs. The increasing energy demand, reducing harmful emissions, and depletion of fossil fuel resources inevitably necessitate for the optimum utilization of exhaustible fossil fuel and non-renewable energy resources. Hence, the scientists are looking for alternative fuels and biodiesel is one of the best available sources to fulfill the energy demand of the world [1-3]. Biodiesel production is not something new, because the concept of using vegetable oil as fuel dates back to 1895 . The first diesel engine was run using groundnut oil as fuel. In 1911, Rudolf Diesel stated that the diesel engine can be fed with vegetable oil and would help considerably in the agricultural development of the countries which use it. In 1912, Rudolf Diesel said, "the use of vegetable oils for engine fuels may seem insignificant today". Although vegetable oils hold promise as alternative fuels [4,5], using raw oils in diesel engines can lead to engine-related problems such as injector coking and piston ring sticking. Biodiesel is a sulfur-free, non-toxic, biodegradable, and oxygenated alternative diesel fuel with a higher cetan number and lubricity [4,6-8]. Many researchers [5,7-14], have studied biodiesel fuels and their blends with petroleum diesel fuel as an alternative energy source in the compression ignition engine, and its performance, emissions and combustion 
characteristics of the engine were analyzed. The results showed that biodiesel fuels provided increase in brake specific fuel consumption (Bsfc) since biodiesel fuels have lower heating values. Based on these studies, biodiesel can be used as a substitute for diesel in diesel engine. Some investigators were examine the effects of using biodiesel as an alternative fuel in a Low Heat Rejection engines, LHR, to determine any significant effects on performance and exhaust gas emissions $[15,16]$.

Some studies show that almost $1 / 3$ of the energy of a fossil fuel is destroyed during the combustion process in power generation. This has caused a renewed interest in exergy analyses, since effective management and optimization of thermal systems is emerging as a major modern technical problem [17]. An exergy-based performance analysis is the performance analysis of a system based on the second law of thermodynamics that overcomes the limit of an energy-based analysis [18]. The equations for the second law analysis of a thermodynamic system are presented and discussed thoroughly $[19,20]$ and are used to analyze the operation of power plants [2123]. However, during the last 20 years, it is well known that using only the first law is inadequate for evaluating some features of energy resource utilization [6,21-23]. For this reason, the use of the second law of thermodynamics has been intensified in internal combustion engines. A series of papers was published on second law or exergy analysis applied to internal combustion engines in the last few decades. A review study was published by Caton [24] and was extended by Rakopoulos et al [25]. It can be seen from these review papers that numerous studies have been performed on the application of exergy analysis to SI engines [26-28] and compression ignition engines using hydrocarbon fuels and/or alternative fuels [29-35]. Various investigators were conducted some studies on exergy analysis of ICEs at fixed dead state temperatures [3031] using same characteristic engines using different fuels. Ertesvag was investigated the variations of chemical exergy for atmospheric gases and gaseous fuels to variations in ambient conditions. Calculating the change of chemical exergy over certain processes showed that separation of air gases is potentially most efficient in cold climates, while water electrolysis to hydrogen is favorable in warmer climates. Combustion reactors and fuel cells are potentially most efficient in cold climates [32]. In addition to that Caliskan et al. [35] were conducted the effects on exergy efficiencies of different dead state temperatures using alternative fuels in a four stroke, four-cylinder, turbocharged diesel engine. The results obtained were shown that exergetic efficiency increased as dead state temperature decreased. The combustion process is the most important stage during IC engine operation and modeling of combustion in a realistic way is very important for exergetic computations. Therefore, many studies have been devoted to the investigations of SI engine [36-39] and CI engine [1,40-41] operations from the second law perspective by using detailed cycle and combustion models.

In this study, the First and Second Laws of thermodynamics are employed to analyze the quantity and quality of energy in a four-stroke, four-cylinder, water cooled, $46 \mathrm{~kW}$ capacity direct injection diesel engine using No.2 diesel fuel and soybean oil methyl ester (SME) as biodiesel fuel. Performance parameters of the engine for each fuel, namely the brake specific fuel consumption, fuel energy, brake thermal efficiency, heat and exhaust losses, fuel exergy, exergetic efficiency, exergy loss accompanying heat loss, exergy loss accompanying the exhaust gas, and exergy destroyed in the engine, were computed and compared with each other. 


\subsection{Energy Analysis}

\section{THEORETICAL ANALYSIS}

Most transient-flow processes can be modeled as a uniform flow process. With the purpose of simplifying the first law calculations of the test engine, the following assumptions were made; the engine operates at steady-state, the whole engine, including the dynamometer, is selected as a control volume, the combustion air and the exhaust gas each forms ideal gas mixtures and potential and kinetic energy effects of the incoming and outgoing fluid streams are ignored. After these assumptions, fuel energy rate to the control volume is given by Eqs.(1)

$\dot{\mathrm{Q}}_{\mathrm{f}}=\dot{\mathrm{m}}_{\mathrm{f}} \cdot \mathrm{LHV}$

Where LHV is the lower heating value $(\mathrm{kJ} / \mathrm{kg})$ and $\dot{\mathrm{m}}_{\mathrm{f}}$ is the mass flow rate of fuel $(\mathrm{kg} / \mathrm{s})$, respectively. Effective torque and power of the engine are determined by Equation 2 and 3.

$$
\begin{aligned}
& \mathrm{M}_{\mathrm{e}}=0.25 \cdot \mathrm{L} \quad(\mathrm{Nm}) \\
& \mathrm{P}_{\mathrm{e}}=\omega \cdot \mathrm{M}_{\mathrm{e}}=\frac{2 \cdot \pi \cdot \mathrm{M}_{\mathrm{e}} \cdot \mathrm{n}}{60} \cdot 10^{-3}
\end{aligned}
$$

Where $\mathrm{L}$ is measured engine load and $\omega, \mathrm{M}_{\mathrm{e}}$ and $\mathrm{n}$ represent to angular velocity $(\mathrm{rad} / \mathrm{s})$, engine torque $(\mathrm{Nm})$, and engine speed $(\mathrm{rpm})$, respectively. After that brake specific fuel consumption, bsfc, can be calculated by following relation.,

$$
\mathrm{bsfc}=\frac{\dot{\mathrm{m}}_{\mathrm{f}}}{\mathrm{P}_{\mathrm{e}}} \cdot 3600 \quad(\mathrm{~g} /(\mathrm{kW} \cdot \mathrm{h}))
$$

Total exhaust heat $\left(\dot{\mathrm{Q}}_{\mathrm{ex}}\right)$, the overall heat in the exhaust gases expressed as a rate of energy flow is given by Eq.(5).

$$
\dot{\mathrm{Q}}_{\mathrm{ex}}=\frac{\dot{\mathrm{m}}_{\mathrm{gw}} \mathrm{C}_{\mathrm{p}, \mathrm{w}}\left(\mathrm{T}_{\mathrm{w} 2}-\mathrm{T}_{\mathrm{w} 1}\right)}{\left(\mathrm{T}_{\mathrm{e} 2}-\mathrm{T}_{\mathrm{e} 3}\right)} \cdot\left(\mathrm{T}_{\mathrm{e} 1}-\mathrm{T}_{0}\right)
$$

Where; $\dot{\mathrm{m}}_{\mathrm{gw}}$ : mass flow rate of calorimeter cooling water $(\mathrm{kg} / \mathrm{s}) ; \mathrm{C}_{\mathrm{pw}}$ : specific heat of the calorimeter cooling water $(\mathrm{kJ} / \mathrm{kgK}) ; \mathrm{T}_{\mathrm{wl}}$ : cooling water inlet temperature $\left({ }^{\circ} \mathrm{C}\right) ; \mathrm{T}_{\mathrm{w} 2}$ : cooling water outlet temperature $\left({ }^{\circ} \mathrm{C}\right) ; \mathrm{T}_{\mathrm{e} 1}$ : Exhaust gas temperature at engine $\left({ }^{\circ} \mathrm{C}\right) ; \mathrm{T}_{\mathrm{e} 2}$ : Exhaust gas temperature at inlet to calorimeter $\left({ }^{\circ} \mathrm{C}\right) ; \mathrm{T}_{\mathrm{e} 3}$ :exhaust gas temperature at outlet from calorimeter $\left({ }^{\circ} \mathrm{C}\right) ; \mathrm{T}_{0}$ : ambient air temperature $\left({ }^{\circ} \mathrm{C}\right)[26,34]$.

Total heat loss to be consisting of cooling water and radiation heat is determined by Eq.(6). Thermal efficiency of the control volume (energy percentage), $\eta_{\text {th }}$, is usually determined as the ratio of the power output (net work) to the fuel energy input and determined by Eq.(7).

$\dot{\mathrm{Q}}_{\mathrm{thl}}=\dot{\mathrm{Q}}_{\mathrm{f}}-\left(\mathrm{P}_{\mathrm{e}}+\dot{\mathrm{Q}}_{\mathrm{ex}}\right)$

$\eta_{\text {th }}=\frac{\text { Useful output }}{\text { Energy Input (Fuel's Heating Value) }}=\frac{\mathrm{P}_{\mathrm{e}}}{\dot{\mathrm{Q}}_{\mathrm{f}}}=\frac{\mathrm{P}_{\mathrm{e}}}{\dot{\mathrm{m}}_{\mathrm{f}} \cdot \mathrm{LHV}}$ 


\subsection{Exergy Analysis}

Unlike energy, the value of exergy depends on the state of the environment as well as the state of the system. Therefore, exergy is a combination property. The exergy analysis of thermal systems is performed to improve energy source utilization by determining the order of exergy destructions and losses in the processes and components of the system and then by reducing them. In principle, four different type of exergy can be identified. These are denoted, respectively, as kinetic, potential, physical and chemical exergy, viz.: The specific flow exergy of a fluid stream (e) is obtained from this sum, Eq. (8). However, exergy is the sum of the thermo mechanical, $\left(\mathrm{e}_{\mathrm{tm}}=\mathrm{e}_{\text {Pot }}+\mathrm{e}_{\text {kin }}+\mathrm{e}_{\text {phy }}\right)$, and chemical exergies. $\mathrm{e}_{\mathrm{tm}}$ and $\mathrm{e}_{\mathrm{ch}}$ are thermo mechanical and chemical exergies, respectively. Thermo mechanical exergy is defined as Eq.(9) $[20,22,23]$.

$$
\begin{aligned}
& \mathrm{e}=\mathrm{e}_{\text {Pot }}+\mathrm{e}_{\text {kin }}+\mathrm{e}_{\text {phy }}+\mathrm{e}_{\mathrm{ch}}=\mathrm{e}_{\mathrm{tm}}+\mathrm{e}_{\mathrm{ch}} \\
& \mathrm{e}_{\mathrm{tm}}=\mathrm{h}-\mathrm{h}_{\mathrm{o}}-\mathrm{T}_{\mathrm{o}} \cdot\left(\mathrm{s}-\mathrm{s}_{\mathrm{o}}\right)
\end{aligned}
$$

Where $\mathrm{h}$ and $\mathrm{s}$ are flow enthalpy and flow entropy per unit mass at the relevant temperature and pressure, respectively, while $\mathrm{h}_{0}$ and $\mathrm{s}_{0}$ stand for the corresponding values of these properties when the fluid comes to equilibrium with the reference environment. The specific chemical exergies of liquid fuels can be evaluated from the following expression on a unit mass basis $[6,29,34]$.

$$
\mathrm{e}_{\mathrm{f}}^{\mathrm{ch}}=\left[1.0401+0.1728 \frac{\mathrm{h}}{\mathrm{c}}+0.0432 \frac{\mathrm{o}}{\mathrm{c}}+0.2169 \frac{\mathrm{s}}{\mathrm{c}}\left(1-2.0628 \frac{\mathrm{h}}{\mathrm{c}}\right)\right] \cdot|\mathrm{LHV}|
$$

$\mathrm{h}, \mathrm{c}, \mathrm{o}$, and $\mathrm{s}$ are the mass fractions of $\mathrm{H}, \mathrm{C}, \mathrm{O}$, and $\mathrm{S}$, respectively. Chemical exergies of No.2 diesel fuel $\left(\mathrm{C}_{16} \mathrm{H}_{34}\right)$, and biodiesel $\left(\mathrm{C}_{18.74} \mathrm{H}_{34.43} \mathrm{O}_{2}\right)$ were computed using this equation, and the values are presented in Table 1 . In addition to this, the definition of environment adopted in this study was received from ref. 22,23.

Table 1. Elemental analysis of No.2 diesel fuel and biodiesel [6].

\begin{tabular}{|l|l|l|}
\hline Elements & Number 2 Diesel & Biodiesel \\
\hline $\mathrm{h} / \mathrm{c}$ & 0.14657 & 0.15317 \\
\hline $\mathrm{o} / \mathrm{c}$ & - & 0.14228 \\
\hline $\mathrm{s} / \mathrm{c}$ & 0.00047 & 0.000064 \\
\hline
\end{tabular}

Thermo mechanical exergy of an ideal gas mixture at the temperature $T$ and pressure $p$ and containing $\mathrm{n}$ components is;

$$
\overline{\mathrm{e}}_{\mathrm{tm}}=\sum_{\mathrm{i}=1}^{\mathrm{n}} \mathrm{a}_{\mathrm{i}}\left\{\overline{\mathrm{h}}_{\mathrm{i}}(\mathrm{T})-\overline{\mathrm{h}}_{\mathrm{i}}\left(\mathrm{T}_{\mathrm{o}}\right)-\mathrm{T}_{\mathrm{o}}\left[\overline{\mathrm{s}}^{\mathrm{o}}(\mathrm{T})-\overline{\mathrm{s}}^{\mathrm{o}}\left(\mathrm{T}_{\mathrm{o}}\right)-\overline{\mathrm{R}} \ln \frac{\mathrm{p}}{\mathrm{p}_{\mathrm{o}}}\right]\right\}
$$

Where $a_{i}$ is the coefficient of the component $i$ in the reaction equation, $\bar{s}^{0}$ is the absolute entropy at the standard pressure $(\mathrm{kJ} / \mathrm{kmol}-\mathrm{K})$, and $\overline{\mathrm{R}}$ is the universal gas constant $(8.314 \mathrm{~kJ} / \mathrm{kmol}-\mathrm{K})$. On the other hand, assuming the ideal solution assumption is valid; the specific chemical exergy for a multi component stream 
can be calculated as $\overline{\mathrm{e}}_{\mathrm{ch}}=\overline{\mathrm{R}} \mathrm{T}_{0} \sum_{\mathrm{i}=1}^{\mathrm{n}} \mathrm{a}_{\mathrm{i}} \ln \left(\frac{\mathrm{y}_{\mathrm{i}}}{\mathrm{y}_{\mathrm{i}}^{\mathrm{e}}}\right)$

where $y_{i}$ is the molar ratio of the $i$ th component in the exhaust gas and $\mathrm{y}_{\mathrm{i}}^{\mathrm{e}}$ is the molar ratio of the $i$ th component in the reference environment. The exergy balance relation below can be stated as the rate of exergy change within the control volume during a process is equal to the rate of net exergy transfer through the control volume boundary by heat, work, and mass flow minus the rate of exergy destruction within the boundaries of the control volume. And finaly, exergy rate balance relation is given by Eq. (13).

$\underbrace{\sum_{\mathrm{s}}\left(1-\frac{\mathrm{T}_{\mathrm{o}}}{\mathrm{T}}\right) \dot{\mathrm{Q}}_{\mathrm{cv}}}_{\begin{array}{c}\text { Exergy transfer } \\ \text { by heat }\end{array}}-\underbrace{\dot{\mathrm{W}}_{\mathrm{cv}}}_{\begin{array}{c}\text { Exergy transfer } \\ \text { by work }\end{array}}+\underbrace{\sum_{\text {in }} \dot{\mathrm{m}} \cdot \mathrm{e}-\sum_{\text {out }} \dot{\mathrm{m}} \cdot \mathrm{e}}_{\begin{array}{c}\text { Exergy transfer } \\ \text { by mass }\end{array}}-\dot{\mathrm{E}}_{\text {destroyed }}=\Delta \dot{\mathrm{E}}_{\text {system }}$ and

$$
\dot{\mathrm{E}}_{\mathrm{d}}=\mathrm{T}_{\mathrm{o}} \mathrm{S}_{\text {gen }}
$$

$\mathrm{T}$ indicates the absolute temperature at the location on the boundary where the heat transfer occurs. The terms of $\sum_{\text {in }} \dot{\mathrm{m}} \cdot \mathrm{e}$ and $\sum_{\text {out }} \dot{\mathrm{m}} \cdot \mathrm{e}$ show the rate of exergy entering and leaving the control volume accompanying the fuel stream, respectively. Finally, $\dot{\mathrm{E}}_{\mathrm{d}}$ represents the rate of exergy destroyed in the control volume due to irreversibilities. When computing the rate of exergy transfer accompanying heat transfer, it was assumed that $\dot{\mathrm{Q}}_{\mathrm{cv}}$ is rejected into the ambient air from the boundary having the same temperature as the engine coolant exiting the engine block. Inserting values for the exergy transfers accompanying heat, mass flow, and power transfers, the rate of exergy destruction in the engine can be determined by the Eq. (14). Also, exergetic efficiencies are useful for distinguishing means for utilizing energy resources that are thermodynamically effective from those that are less so. Exergetic efficiencies also can be used to evaluate the effectiveness of engineering measures taken to improve the performance of a thermal system. Finally, the exergetic efficiency of the engine (Eq.(15)) can be evaluated from the ratio of the power output to the fuel exergy input $[20,22,23,35]$.

$$
\begin{gathered}
\dot{\mathrm{E}}_{\mathrm{f}}=\dot{\mathrm{m}}_{\mathrm{f}} \cdot \mathrm{e}_{\mathrm{f}}^{\mathrm{ch}} \\
\begin{array}{c}
\text { Fuel exergy) } \\
\mathrm{h}_{\mathrm{II}}=\frac{\dot{\mathrm{E}}_{\mathrm{Q}}=\sum_{\mathrm{s}}\left(1-\frac{\mathrm{T}_{\mathrm{o}}}{\mathrm{T}}\right) \dot{\mathrm{Q}}}{\text { Work exergy }} \\
\text { Exergy supplied }
\end{array}=\frac{\dot{\mathrm{E}}_{\mathrm{W}}}{\dot{\mathrm{E}}_{\mathrm{f}}}=1-\frac{\text { Exergy destroyed }}{\text { Fuel exergy }}=1-\frac{\dot{\mathrm{E}}_{\mathrm{d}}}{\dot{\mathrm{E}}_{\mathrm{f}}}
\end{gathered}
$$

\section{EXPERIMENTAL STUDIES}

In this study, the experimental set up consists of a compression ignition engine, engine test bed with a GoPower brand hydraulic dynamometer, exhaust calorimeter and a gas analyzer. The schematic view of the experimental set up is shown in Fig. 1. A 
Steyr brand, four cylinder, four-stroke, water cooled compression-ignition engine was used in the experiments.

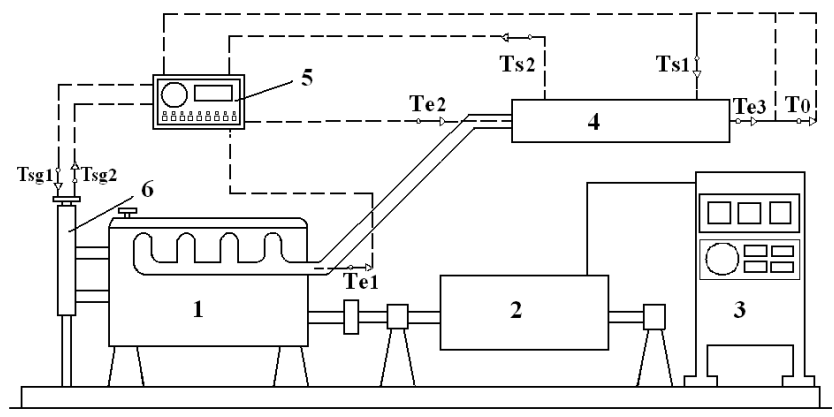

1. Test engine

2. Dynamometer

3. Control board

4. Exhaust calorimeter

5. Temperature indicator

6. Cooling tower

Fig. 1. Schematic view of engine test unit.

The test engine has a bore of $100 \mathrm{~mm}$, a stroke of $100 \mathrm{~mm}$, a compression ratio of 16.1:1, and a maximum power output of $46 \mathrm{~kW}$ at $2400 \mathrm{rpm}$. The dynamometer used was a capable of absorbing a maximum load of $100 \mathrm{~kW}$ at a speed of $4000 \mathrm{rpm}$. A strain gauge based load cell system was used for load measurement. A scale (type Ohaus GT8000) and stopwatch were used for measurement of the fuel flow rate. Air flow measurement was carried out using a capacity damping tank and interchangeable orifice plates designed to cover the engine ranges supplied. Two flow meters were used for measurement of the cooling water flow rate (engine and calorimeter). Type $\mathrm{K}$ thermocouples and digital thermometer with 12 channels were used for temperature measurements. An extra fuel tank was used for biodiesel fuel storage. Diesel fuel and soybean oil methyl ester used as fuel. Some important properties and compositions of the fuels are shown in Table 2. The experiments were conducted at $100 \mathrm{Nm}$ at $2000 \mathrm{rpm}$ after completion of a standard warm up procedure without modifications to engine or injection system using the pure fuels of No.2 diesel and biodiesel, respectively.

Table 2. Some properties of the fuels used in the tests [6,20,42].

\begin{tabular}{|l|l|l|}
\hline Property & No.2 diesel fuel & Biodiesel (SME) \\
\hline Typical formula & $\mathrm{C}_{16} \mathrm{H}_{34}$ & $\mathrm{C}_{18.74} \mathrm{H}_{34.43} \mathrm{O}_{2}$ \\
\hline Average molecular weight $\left(\mathrm{kg} \mathrm{kmol}^{-1}\right)$ & 226.446 & 834.388 \\
\hline Density $\left(\mathrm{kg} \mathrm{m}^{-3}\right)$ & 815 & 872 \\
\hline Lower heating value $\left(\mathrm{kJ} \mathrm{kg}^{-1}\right)$ & 43350 & 39760 \\
\hline Cetan number & 47 & 55 \\
\hline Fuel exergy values at $100 \mathrm{Nm}(\mathrm{kW})$ & 76.054 & 72.337 \\
\hline
\end{tabular}

\section{RESULTS AND DISCUSSION}

\subsection{Brake specific fuel consumption}

The brake specific fuel consumption values of tested fuels are seen in Fig. 2. The brake specific fuel consumption for usage of biodiesel results in $13.86 \%$ higher than that of No.2 diesel fuel. Brake specific fuel consumption (Bsfc) is the ratio between mass fuel consumption and effective power. Specific fuel consumption when using a biodiesel fuel is expected to increase by around $14 \%$ in relation to the consumption with diesel fuel, corresponding to the increase in heating value in mass basis. In other words, the loss of heating value of biodiesel must be compensated with higher fuel 
consumption. An indicator of the loss of heating value, and thus of the expected fuel consumption is the oxygen content in the fuel. Finally, the increased fuel flow in the case of biodiesel in conjunction with the higher density of biodiesel compared to No.2 diesel fuel (Table 3 ) resulted in the increased fuel mass used and hence higher Bsfc $[3,6,13,15,21]$.

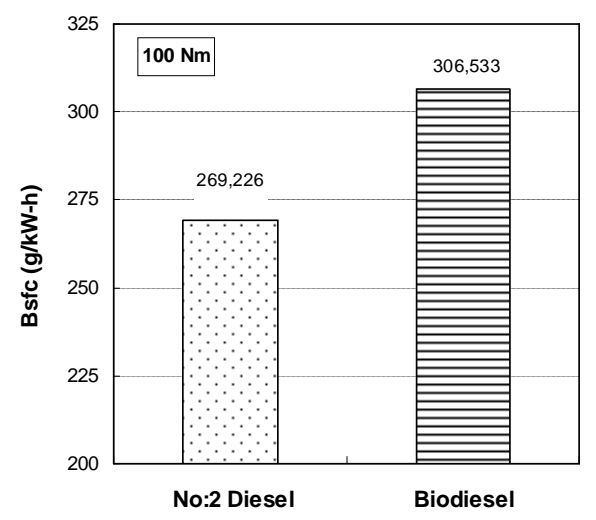

Fig. 2. Bsfc values of test fuels.

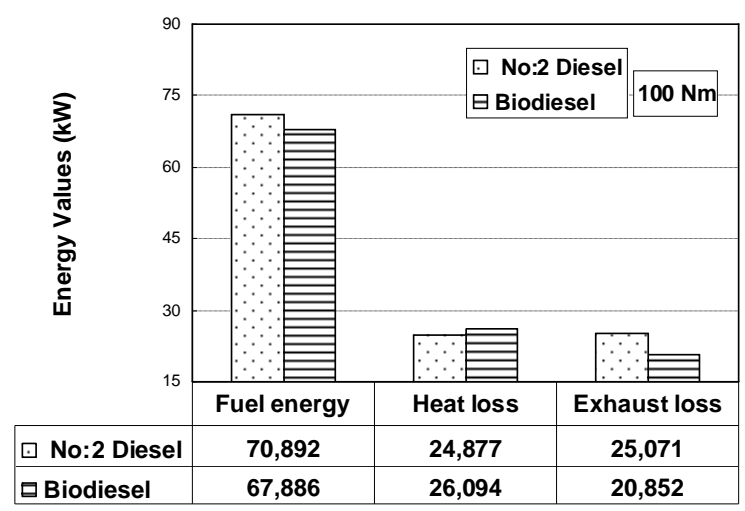

Fig. 3. Energy values of test fuels.

\subsection{Energy and loss energy values}

The fuel energy values, $\dot{\mathrm{Q}}_{\mathrm{f}}$, entering the engine with each fuel and lossing energy values (heat transfer and exhaust losses) are shown in Fig. 3. The biodiesel fuel provided slightly less energy to the engine than No. 2 diesel fuel to give the same power output of $20.944 \mathrm{~kW}$. Because the Lower Heating Value, LHV, of the biodiesel (39760 $\mathrm{kJ} / \mathrm{kg})$ is $8.2 \%$ lower than the LHV of diesel fuel $(43350 \mathrm{~kJ} / \mathrm{kg})$, a lower amount of fuel energy is required to produce this output power. Finally, fuel energy is direct proportional with the lower heating value of the fuel and thus the fuel energy entering the engine for the biodiesel is lower than the diesel fuel [2]. The operation with biodiesel fuel results in higher rate of heat transfer from the engine. When the engine is fuelled with biodiesel, it rejects approximately $4.9 \%$ higher rate of heat into the atmosphere, compared to No. 2 diesel fuel. The use of biodiesel fuel yields lower CO and unburned HC concentrations in the exhaust gas and this is also attributable to the promotion of better combustion with biodiesel fuel. Therefore, a higher rate of total energy in the forms of heat and work is transferred from the engine in the operation with biodiesel fuel. Finally, because the engine power output is the same for the each fuel, the exhaust loss is a function of only the difference between fuel energy input and the heat loss energy from the engine and also this result in higher heat transfer rates from the engine for biodiesel [6]. Also, the variation in exhaust temperatures can be attributed to the increase in thermal efficiency and/or the decrease in the combustion temperatures. The increase in thermal efficiency means that a larger portion of combustion heat has been converted into work and therefore lower exhaust temperatures can be expected. In addition to this, due to high concentrations of $\mathrm{HC}$ and $\mathrm{CO}$ in the exhaust gas, the operation with No. 2 diesel fuel yields the higher exhaust energy loss (approximately $20 \%$ ), compared to biodiesel fuel. Finally, the more the heat transfer decreases, the more the energy lost to the exhaust increases even though the thermal efficiency increase $[6,15,16]$. 


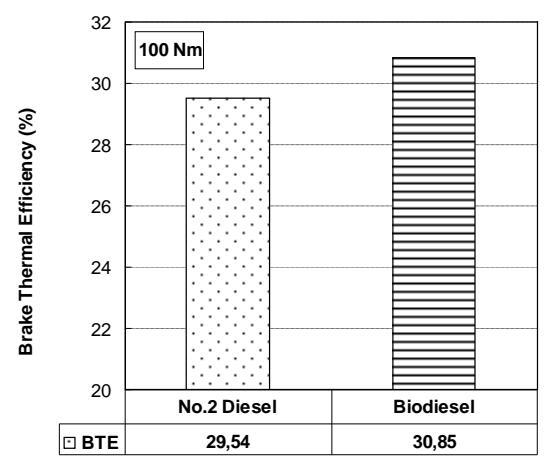

Fig. 4. Brake thermal efficiency values of the using fuels.

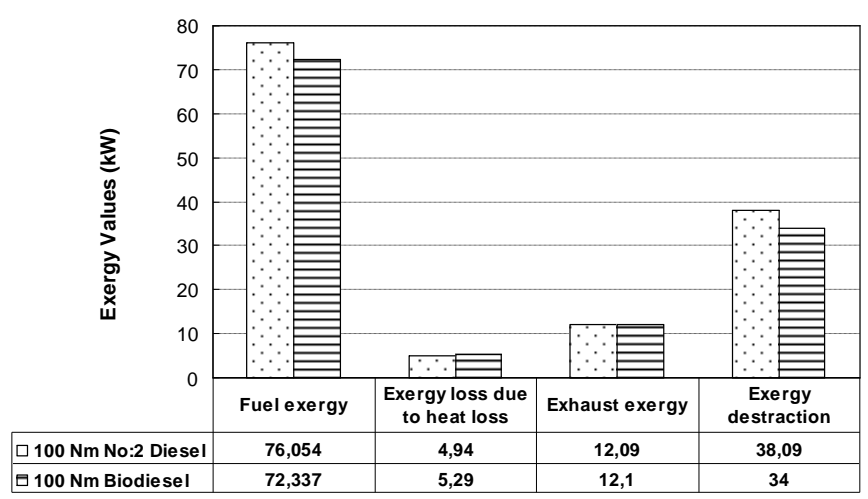

Fig. 5. Exergy values of the using fuels.

The brake thermal efficiencies for the tested fuels can be seen in Fig. 4. This indicates the engine's ability to convert chemical energy to mechanical energy. The engine operation biodiesel fuel yields approximately $1.3 \%$ higher thermal efficiency compared to No. 2 diesel fuel. Brake thermal efficiency is the ratio of brake power to the fuel energy input and because of same brake power and great fuel energy input with biodiesel. It is noticed that the use of oxygen-rich biodiesel fuels promote a better mixture formation and combustion, thus improving the thermal efficiency [8,35]. The improvement in brake thermal efficiency can be attributed to the enhanced oxygen content which improves combustion especially during the phase of diffusion combustion, and to the higher lubricity of biodiesel which reduces the friction loss.

\subsection{Fuel Exergy, Heat Loss Exergy, Exhaust Exergy And Exergy Destruction}

The exergy values of the tested fuels are presented in Fig. 5. Since the specific fuel exergy is aligned to the lower heating value, the fuel exergy values for the either fuel are sustain a similarity to the fuel energy values in Fig. 3. However, it is seen that the fuel exergy inputs are approximately $7.3 \%$ and $6.6 \%$ higher than the diesel No.2 and biodiesel fuel energy inputs, respectively. Since exergy loss accompanying heat loss from the engine is proportional to the rate of heat rejection, the heat loss exergy values presented here are analogous to heat loss energy values given in Fig. 3. One item, which needs to be mentioned, is the fact that heat transfers create all the more irreversibilities, as the temperature difference of the transferring surfaces is significant. So to maximize exergy transfer during heat transfer, temperature gap needs to be low. The higher the temperature of the engine surface occurring the heat loss, the higher the exergy loss accompanying it. For the No.2 diesel and biodiesel fuels' calculation results show that $6.49 \%$ and $7.31 \%$ of the fuel exergy input is lost manner the heat transfer from the engine, respectively [28,29]. The exergy loss due to the exhaust gas and concentrations of $\mathrm{CO}$ and $\mathrm{HC}$ in the exhaust gas can be decreased by reducing the exhaust gas temperature $[14,27]$. As seen in this figure, there is some improvement in operation with biodiesel. Exergy is not conserved, and the irreversible processes in the engine, such as combustion, heat transfer, mixing, friction, etc., destroy a significant fraction of the fuel exergy. Due to the rate of exergy destroyed in the engine increases with increasing the combustion temperature, this exergy destruction can be reduced by preheating the 
combustion air and by reducing the amount of excess air. However, the higher temperatures may result in higher heat transfer which will remove the available energy. Also, if not utilized, the higher availability will be expelled with the exhaust gases. Furthermore, another consideration would be the potential for higher nitric oxide $\left(\mathrm{NO}_{\mathrm{X}}\right)$ formation rates at these higher temperatures [24-27].

\subsection{Exergetic Efficiency Values and Energy Distributions for the Tested Fuels}

The first- and second-law efficiencies are similar in characteristics but different in magnitude as seen in the Fig. 6. The first-law efficiency is higher for biodiesel because of same brake power and great fuel energy input with biodiesel. It is seen that the fuel exergy inputs of No.2 diesel and biodiesel fuels are $6.7 \%$ and $6.1 \%$ higher than the corresponding fuel energy inputs. At the same time, exergetic efficiencies of the engine also follow similar trends with the brake thermal efficiencies presented in Fig. 3. Since the engine uses a higher amount of fuel exergy compared to the fuel energy values for the same fuels, the exergetic efficiencies are $6.8 \%$ and $6.2 \%$ lower than the corresponding brake thermal efficiencies [37].

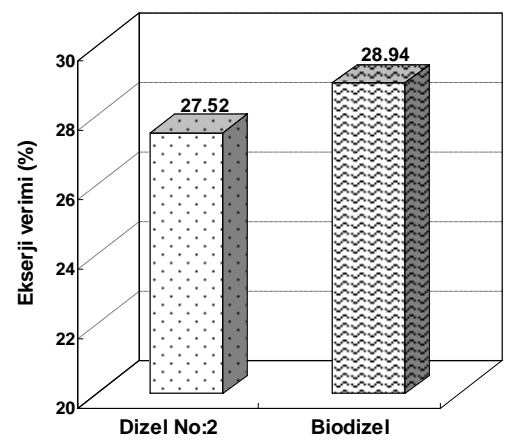

Fig. 6. Exergetic efficiency values for the tested fuels.
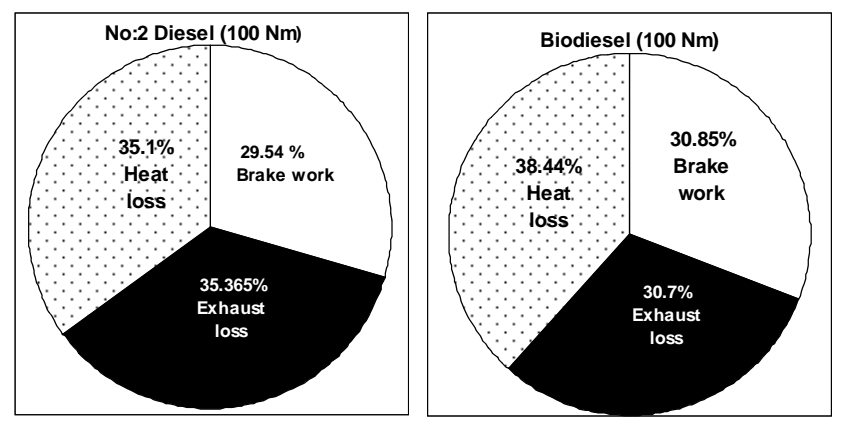

Fig. 7. Energy distribution based on input energy values of the tested fuels.

\subsection{Energy and Exergy Distributions for the Tested Fuels}
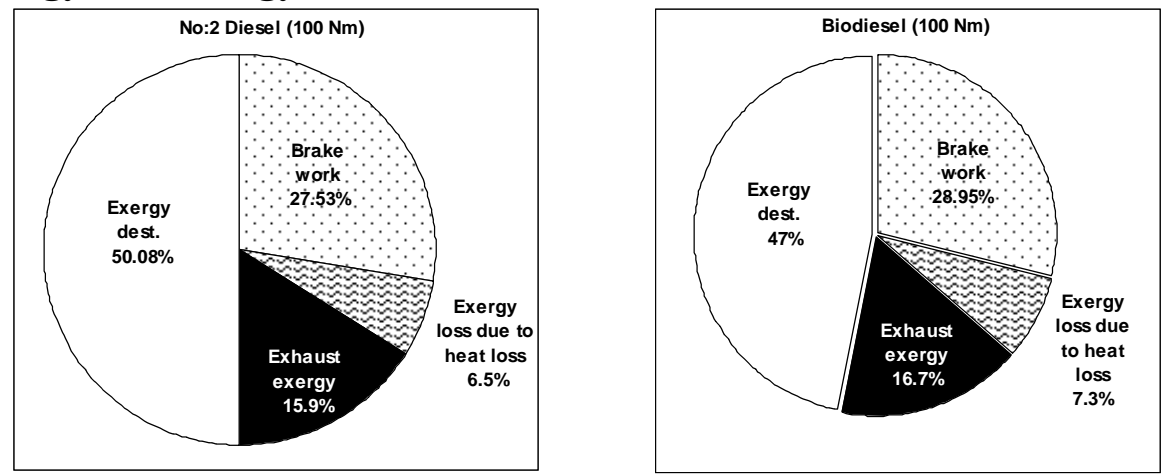

Fig. 8. Distribution of the fuel exergy values for the tested fuels.

Breakdown of the fuel energy for No. 2 diesel, and biodiesel fuels are presented in Fig. 7. In the No. 2 diesel fuel operation, because of the higher exhaust temperature the energy loss accompanying the exhaust gas is higher than in biodiesel fuel. Consequently, for the same power output, operation with biodiesel yields higher rate of heat transfer from the engine. Breakdown of the fuel exergy belonging to the test fuels 
are seen in Fig. 8. Results show that operation with biodiesel yields less exergy destruction and higher power output percentages. Consequently, exergetic efficiency for biodiesel operation is higher compared to No. 2 diesel fuel [6].

\section{CONCLUSIONS}

In this study, test engine was operated at steady-state without modifications to engine or injection system. Using data gathered from the present study, energy and exergy balances to the engine were performed for the either fuel. And then, energetic end exergetic performance parameters of the engine computed and compared with each other. According to the existing study; using exergy as a measure of quality, the petroleum diesel fuel is a greater quality fuel than biodiesel. Because of the net calorific value of diesel is greater than that of the biodiesel. It means that to cover the same distance, greater amount of biodiesel is needed. In addition to this, using of biodiesel fuel shows the similar energetic performance values with that of No. 2 diesel fuel. Likewise, the use of biodiesel develops similar exergetic performance values with No. 2 diesel fuel. The most important factor of the system inefficiency is the destruction of exergy by irreversible processes. This is mainly occured by the combustion. Exergy losses due to the exhaust gas and heat transfer are other contributors in decreasing order. In addition to these results, this study reveals that a combined energy and exergy analysis provides a much better and more realistic answer.

\section{REFERENCES}

1. S. Mukul, R. Agarwal, Energy and Exergy Analysis of Brayton-Diesel Cycle, Proceedings of the World Congress on Engineering Vol II, July 1-3, 2009, London, U.K, ISBN:978-988-18210-1-0

2. S.J. Wallace, Diesel Engine Energy Balance Study Operating on Diesel and Biodiesel Fuels, MSc Thesis The Depart. of Mech. Engineering and the Russ College of Engineering and Technology, 2007

3. S.A.Basha, K.R.Gopal, S.Jebaraj, A Review on Biodiesel Production, Combustion, Emissions and performance., Renewable\&Sust. En.Reviews 13(6-7), 1628-1634, 2009.

4. A. Murugesan, C. Umarani, R. Subramanian, N. Nedunchezhian, Biodiesel as an Alternative Fuel for Diesel Engines-A Review, Renewable and Sustainable Energy Reviews, 13(3), 653-662, 2009.

5. P.K. Sahoo, L.M. Das, Combustion Analysis of Jatropha, Karanja and Polanga Based Biodiesel As Fuel In a Diesel Engine, Fuel, 88(6), 994-999, 2009.

6. M. Canakci, M. Hoşöz, Energy and Exergy Analyses of a Diesel Engine Fuelled with Various Biodiesels, Energy Sources, Part B, 1(4), 379-394, 2006,

7. M. Zheng, C.M. Mwila, G.T. Reader, M. Wang, D.S.K. Ting, J. Tjong, Biodiesel Engine Performance and Emissions in Low Temperature Combustion, Fuel, 87(6), 714-722, 2008.

8. Y. Sekmen, Use of Watermelon and Flax Seed Oil Methyl Estera as a Fuel in a Diesel Engine, Technology, 10(4), 295-302, 2007. 
9. A.N. Onsezen, M. Canakci, A. Turkcan, C. Sayin, Performance and Combustion Characteristics of a DI Diesel Engine Fueled with Waste Palm Oil and Canola Oil Methyl Esters, Fuel, 88(4), 629-636, 2009.

10. N.R. Banapurmath, P.G. Tewari, V.S. Yaliwal, S. Kambalimath, Y.H. Basavarajappa, Combustion Characteristics of a 4-Stroke CI Engine Operated on Honge Oil, Neem and Rice Bran Oils When Directly Injected and Dual Fuelled with Producer Gas Induction, Renewable Energy, 34(7), 1877-1884, 2009.

11. J. Krah, G. Knothe, A. Munack, Y. Ruschel, O. Schröder, E. Hallier, G. Westphal, J. Bünger, Comparison of Exhaust Emissions And Their Mutagenicity From The Combustion of Biodiesel, Vegetable Oil, Gas-To-Liquid and Petrodiesel Fuels, Fuel, 88(6), 1064-1069, 2009.

12. Z. Utlu, M.S. Koçak, The Effect of Biodiesel Fuel Obtained From waste Frying Oil on Direct Injection Diesel Engine Performance and Exhaust Emissions, Renewable Energy, 33(8), 1936-1941, 2008.

13. A. Murugesan, C. Umarani, T.R. Chinnusamy, M. Krishnan, R. Subramanian, N. Neduzchezhain, Production and Analysis of Bio-Diesel From Non-Edible Oils-A Review, Renewable\&Sust. Energy Reviews, 13(4), 825-834, 2009.

14. Y. Di, C.S. Cheung, Z. Huang, Comparison of The Effect of Biodiesel-Diesel and Ethanol-Diesel on The Gaseous Emission of a Direct-Injection Diesel Engine, Atmospheric Environment, 43(17), 2721-2730, 2009.

15. C. Haşimoğlu, M. Ciniviz, I. Özsert, Y. İçingür, A. Parlak, M.S. Salman, Performance Characteristics of a Low Heat Rejection Diesel Engine Operating with Biodiesel, Renewable Energy, 33(7), 1709-1715, 2008.

16. H. Hazar, Effects of Biodiesel on a Low Heat Loss Diesel Engine, Renewable Energy, 34(6), 1533-1537, 2009.

17. R. Graves, S. Daw, J. Conklin, V. K. Chakravarthy, Stretch Efficiency in Combustion Engines with Implications of New Combustion Regimes, FY 2004 Progress Report, 2004.

18. C.D. Rakopoulos, E.G. Giakoumis, The Influence of Cylinder Wall Temperature Profile on the Second-Law Diesel Engine Transient Response, Applied Thermal Engineering, 25(11-12), 1779-1795, 2005.

19. M.J. Moran, and H.N. Shapiro, Fundamentals of Engineering Thermodynamics, 2nd Edition, Wiley New York, 2000.

20. Y.A. Çengel, and M.A Boles, Thermodynamics An Enginnering Approach, $5 \mathrm{ft}$ Edt., McGraw-Hill, Inc.; 2005.

21. M.A. Rosen, I. Dincer, Exergy-Cost-Energy-Mass Analysis of Thermal Systems and Processes, Energy Conv.\& Management, 44(10), 1633-1651, 2003.

22. P. Erduranl1, Exergy Analysis for a Power Plant, MSc Thesis, ZKU Graduate School of Natural\&Applied Sciences Dept of Mech. Eng., Zonguldak, 1997.

23. Z. Şahin, The Research for Increasing Exergy Efficiency of Energy Plants with GasSolid Fuels, MSc Thesis, ZKU Graduate School of Natural\&Applied Sciences Dept of Mech. Eng., Zonguldak, 2006.

24. J.A. Caton, On The Destruction of Availability (Exergy) Due to Combustion Processes-with Specific Application to Internal-Combustion Engines, Energy, 25(11), 1097-1117, 2000. 
25. C.D. Rakopoulos, E.G. Giakoumis, Second-law Analyses Applied to Int. Comb. Engines Operation, Progress in Energy\&Comb. Science, 32(1), 2-47, 2006.

26. M. Kopac, L. Kokturk, Determination of Optimum Speed of an Internal Combustion Engine by Exergy Analysis, Int. J. Exergy, 2(1), 40-54, 2005.

27. C. Sayin, M. Hosoz, M. Canakci, and I. Kilicaslan, Energy and Exergy Analyses of a Gasoline Engine, Int. J Energy Research, 31(3), 259-273, 2007.

28. G. Bourhis, and P. Leduc, Energy and Exergy Balances for Modern Diesel and Gasoline Engines, Oil\&Gas Sci.\&Tech.-Rev. IFP, DOI: 10.2516/ogst/2009051;

29. A. Parlak, The Effect of Heat Transfer on Performance of the Diesel Cycle and Exergy of The Exhaust Gas Stream In a LHR Diesel Engine at the Optimum Injection Timing, Energy Conversion and Management, 46(2), 167-179; 2005.

30. M. Kanoğlu, S.K. Işık, and A. Abuşoğlu, Performance Characteristics of a Diesel Engine Power Plant, Energy Conversion and Management, 46(11-12), 1692-1702, 2005.

31. A. Abuşoğlu, M. Kanoğlu, Emission Characteristics Analysis of Diesel Engine Powered Cogeneration, J. of Thermal Science\& Technology, 29(1), 45-53, 2009.

32. I.S. Ertesvag, Sensitivity of Chemical Exergy for Atmospheric Gases and Gaseous Fuels to Variations in Ambient Conditions, Energy Conversion and Management, 48(7), 1983-1995, 2007.

33. Y. Azoumah, J. Blin, T. Daho, Exergy Efficiency Applied for the Performance Optimization of a Direct Injection Compression Ignition (CI) Engine Using Biofuels, Renewable Energy, 34(6), 1494-1500, 2009.

34. Z. Yılbaş1, The Determination of a Diesel Engine Performance with Exergy Analysis, MSc Thesis, ZKU Graduate School of Natural\&Applied Sciences Dept of Mech. Eng., Zonguldak, 2007.

35. H. Caliskan, M.E. Tat, A. Hepbasli, Performance Assessment of an Internal Combustion Engine at Varying Dead (Reference) State Temperatures, Applied Thermal Engineering, 29(16), 3431-3436, 2009.

36. İ. Sezer, and A. Bilgin, Mathematical Analysis of Spark Ignition Engine Operation Via The Combination of The First And Second Laws of Thermodynamics, Proc. R. Soc. A, 464, 3107-3128, 2008.

37. İ. Sezer, and A. Bilgin, Exergy Analysis of SI Engines, Int. J. Exergy, 5(2), 204217, 2008.

38. İ. Sezer, I. Altın and A. Bilgin, Exergetic Analysis of Using Oxygenated Fuels in Spark-Ignition (SI) Engines, Energy \& Fuels, 23(4), 1801-1807, 2009.

39. C.D. Rakopoulos, C.N. Michos, Generation of Combustion Irreversibilities in a Spark Ignition Engine under Biogas-Hydrogen Mixtures Fueling, Int. J. Hydrogen Energy, 34(10), 4422-4437, 2009.

40. B.A. Akash, Effect of Heat Transfer on The Performance of an Air-Standard Diesel Cycle, Int. Comm. In Heat and Mass Transfer, 28(1), 87-95, 2001;

41. Y. Ust, B. Sahin, A. Kodal, Optimization of a Dual Cycle Cogeneration System Based on a New Exergetic Performance Criterion, App. En., 84(11), 1079-1091, 2007.

42. H.S. Yücesu, R. Altın and S. Cetinkaya, Experimental Investigation of Vegetable Oil Usage as Alternative Fuel in Diesel Engines, Turk. J. Engin. Environ. Sci., 25, 39-49, 2001. 